ORIGINAL ARTICLE

\title{
Comparative epidemiology of atopic and non-atopic wheeze and diagnosed asthma in a national sample of English adults
}

\author{
C S Court, D G Cook, D P Strachan
}

Thorax 2002;57:951-957

See end of article for authors' affiliations

.....................

Correspondence to: Professor D G Cook, Department of Public Health Sciences, St George's Hospital Medical School, Cranmer Terrace, London SW17 ORE, UK;

d.cook@sghms.ac.uk

Revised version received 2 May 2002

Accepted for publication

5 June 2002
Background: There is debate as to whether asthma has distinct atopic and non-atopic forms and whether in epidemiological studies asthma cases should be defined by a physician diagnosis or by self-reported asthma symptoms.

Methods: A total of 24952 people aged 11 and over were surveyed as part of the 1995-6 health surveys for England. Participants were asked if they had experienced wheezing in the past year and if they had ever been given a diagnosis of asthma by a doctor. Serum total lgE and house dust mite (HDM) specific lgE were measured.

Results: Wheeze in the past year without an asthma diagnosis was more common in men and older age groups, whereas wheeze with an asthma diagnosis was more common in women and younger people. Both types of wheeze were more common in the lower social classes, among ex-smokers and current smokers, and in urban areas. Thirty two percent of people reporting wheezing and $22 \%$ of those with diagnosed asthma had neither raised total lgE nor HDM lgE. Among the non-atopic subjects the prevalence of wheeze rose with age and lower social class, largely due to an increase in wheeze without diagnosed asthma. In contrast, among atopic subjects there was no overall trend with age or social class, but wheeze with diagnosed asthma decreased with age.

Conclusions: Clear epidemiological differences are evident between adult wheeze with and without an asthma diagnosis and between atopic and non-atopic wheeze. Subjects with diagnosed asthma are more likely to be atopic, but the results challenge the premise that adult asthma is almost always associated with some lgE mediated reaction.
$\mathrm{F}$ or many years a conceptual distinction has been made between atopic (extrinsic) asthma seen mainly in younger people and non-atopic (intrinsic) asthma seen mostly in older age groups. Many studies have shown that asthmatics have higher total IgE than non-asthmatics. ${ }^{1-4}$ House dust mite (HDM) IgE also has been shown to have a strong association with asthma symptoms in a variety of settings..$^{5-7}$ Burrows et $a l^{1}$ showed that the prevalence of physician diagnosed asthma in the population of Tucson, Arizona was closely related to total IgE even in non-atopic subjects (where atopy was measured by skin prick testing to a range of common allergens). They challenged the concept of allergic and non-allergic forms of asthma, arguing that asthma is almost always associated with an IgE mediated immune reaction and therefore has an allergic basis.

More recent studies have reinforced the concept that total IgE is strongly related to asthma or to non-specific bronchial reactivity in New Zealand children without atopy ${ }^{8}$ and in Spanish adults who lack specific IgE to common aeroallergens. ${ }^{9}$ However, $5 \%$ of the New Zealand children ${ }^{8}$ had recent wheezing without an asthma diagnosis and this was associated with only a slight increase in the mean serum IgE level, while among Spanish adults ${ }^{9}$ current wheezing and other asthma symptoms were positively related to serum total IgE, but much less strongly than was current asthma.

These studies raise two related issues: (1) the contribution of allergy to different forms of asthma/wheeze; (2) the place of physician diagnosed asthma within the broader range of wheezing illness. The latter is particularly relevant given that some studies have relied upon physician diagnosis while many others are purely symptom based.

In this study we have compared the epidemiology of self-reported asthma symptoms without a doctor diagnosis of asthma with those with an asthma diagnosis, and related these to levels of serum total IgE and HDM IgE in a large nationwide study of English adults. We have also explored the extent to which risk factors for asthma symptoms and asthma diagnosis differ according to the level of total and mite specific IgE.

\section{METHODS}

\section{Data source}

The study used data from the health surveys for England for 1995 and 1996. ${ }^{10}{ }^{11}$ These are annual surveys of people living in households in England and are commissioned by the Department of Health. The surveys were conducted in two stages: an initial administered questionnaire followed by a nurse visit for physical measurements and to obtain a blood sample. The questionnaire included recording of age and sex and participants were asked about their smoking habits, whether they had experienced wheezing in the past year, and whether a doctor had ever given them a diagnosis of asthma. The occupation of the head of the household was used to determine social class. Whether the household was in an urban or rural area was also recorded.

Analysis of total and HDM IgE was carried out on serum samples using the Pharmacia CAP system immunoassay method. ${ }^{11}$ Quality control results for 1995 and 1996 have been published..$^{11}{ }^{11}$ Coefficients of variation were $5-10 \%$ for total IgE and 10-20\% for HDM specific IgE. External quality control results showed good agreement between target and achieved values.

\section{Subjects}

A sample of private households in England was selected using a multistage stratified probability sampling design. ${ }^{10}$ Although 


\begin{tabular}{|c|c|c|c|c|c|c|c|}
\hline \multirow[b]{2}{*}{ Total $\lg \mathrm{E}(\mathrm{kU} / \mathrm{l})$} & \multirow[b]{2}{*}{ HDM lgE (kU/l) } & \multicolumn{2}{|c|}{ No wheeze } & \multicolumn{2}{|c|}{$\begin{array}{l}\text { Wheeze in the past year without } \\
\text { a diagnosis }\end{array}$} & \multicolumn{2}{|c|}{$\begin{array}{l}\text { Wheeze in the past year and } \\
\text { diagnosis of asthma }\end{array}$} \\
\hline & & No & $\%$ & No & $\%$ & No & $\%$ \\
\hline $0-3$ & $\begin{array}{l}0-0.3 \\
>0.3\end{array}$ & $\begin{array}{r}2036 \\
21\end{array}$ & $\begin{array}{l}85.7 \\
87.5\end{array}$ & $\begin{array}{r}247 \\
2\end{array}$ & $\begin{array}{r}10.4 \\
8.3\end{array}$ & $\begin{array}{r}94 \\
1\end{array}$ & $\begin{array}{l}4.0 \\
4.2\end{array}$ \\
\hline $4-9$ & $\begin{array}{l}0-0.3 \\
>0.3\end{array}$ & $\begin{array}{r}2435 \\
43\end{array}$ & $\begin{array}{l}85.4 \\
76.8\end{array}$ & $\begin{array}{r}313 \\
5\end{array}$ & $\begin{array}{r}11.0 \\
8.9\end{array}$ & $\begin{array}{r}103 \\
8\end{array}$ & $\begin{array}{r}3.6 \\
14.3\end{array}$ \\
\hline $10-31$ & $\begin{array}{l}0-0.3 \\
>0.3\end{array}$ & $\begin{array}{r}4763 \\
329\end{array}$ & $\begin{array}{l}83.6 \\
79.9\end{array}$ & $\begin{array}{r}678 \\
44\end{array}$ & $\begin{array}{l}11.9 \\
10.7\end{array}$ & $\begin{array}{r}257 \\
39\end{array}$ & $\begin{array}{l}4.5 \\
9.5\end{array}$ \\
\hline $32-99$ & $\begin{array}{l}0-0.3 \\
>0.3\end{array}$ & $\begin{array}{r}4371 \\
826\end{array}$ & $\begin{array}{l}81.3 \\
73.5\end{array}$ & $\begin{array}{l}682 \\
140\end{array}$ & $\begin{array}{l}12.7 \\
12.5\end{array}$ & $\begin{array}{l}322 \\
158\end{array}$ & $\begin{array}{r}6.0 \\
14.1\end{array}$ \\
\hline $100-315$ & $\begin{array}{l}0-0.3 \\
>0.3\end{array}$ & $\begin{array}{l}2164 \\
1218\end{array}$ & $\begin{array}{l}76.2 \\
68.4\end{array}$ & $\begin{array}{l}414 \\
245\end{array}$ & $\begin{array}{l}14.6 \\
13.7\end{array}$ & $\begin{array}{l}263 \\
319\end{array}$ & $\begin{array}{r}9.3 \\
17.9\end{array}$ \\
\hline $316-999$ & $\begin{array}{l}0-0.3 \\
>0.3\end{array}$ & $\begin{array}{l}523 \\
703\end{array}$ & $\begin{array}{l}71.5 \\
62.9\end{array}$ & $\begin{array}{l}120 \\
159\end{array}$ & $\begin{array}{l}16.4 \\
14.2\end{array}$ & $\begin{array}{r}88 \\
256\end{array}$ & $\begin{array}{l}12.0 \\
22.9\end{array}$ \\
\hline $1000+$ & $\begin{array}{l}0-0.3 \\
>0.3\end{array}$ & $\begin{array}{r}88 \\
254\end{array}$ & $\begin{array}{l}67.2 \\
59.5\end{array}$ & $\begin{array}{l}24 \\
53\end{array}$ & $\begin{array}{l}18.3 \\
12.4\end{array}$ & $\begin{array}{r}19 \\
120\end{array}$ & $\begin{array}{l}14.5 \\
28.1\end{array}$ \\
\hline Total & & 19774 & 79.3 & 3126 & 12.5 & 2047 & 8.2 \\
\hline
\end{tabular}

the study population for the health survey for England covers subjects aged 2 years and over, blood samples were obtained only from people aged 11 and over. This report analyses data only on the latter group from whom a usable blood sample was obtained.

\section{Analysis}

Wheezing with and without an asthma diagnosis

The population was divided into three categories:

(1) No wheezing in the past year.

(2) Wheezing in the past year and no doctor diagnosis of asthma ever.

(3) Wheezing in the past year and a doctor diagnosis of asthma ever.

The distributions of total and HDM IgE in each category were examined. Logistic regression was used to calculate odds ratios for wheeze in the past year without an asthma diagnosis versus no wheeze and for wheeze with an asthma diagnosis versus no wheeze. Adjustment was made for age, sex, social class, smoking status, and urban versus rural location. The analysis was repeated using only those people who had never smoked in order to eliminate any smoking effect.

\section{Atopic $v$ non-atopic wheezing}

The population was divided into non-atopic, intermediate, and atopic categories. Atopic subjects were defined as those with HDM IgE $>0.3 \mathrm{kU} / \mathrm{l}$. This or a similar level has been taken as positive for specific IgE in other studies. ${ }^{12}{ }^{13}$ Non-atopic subjects were defined as those with a total $\operatorname{IgE}$ of $\leqslant 30 \mathrm{kU} / \mathrm{l}$ and HDM IgE $\leqslant 0.3 \mathrm{kU} / \mathrm{l}$. The intermediate group was those with a total IgE of $>30 \mathrm{kU} / \mathrm{l}$ and HDM IgE $\leqslant 0.3 \mathrm{kU} / \mathrm{l}$.

Odds ratios were calculated for wheeze in the past year compared with no wheeze for the atopic and non-atopic categories with adjustment for age, sex, social class, smoking status, and urban location.

\section{Risk factors for atopic and non-atopic wheeze}

In order to illustrate patterns of wheezing in each category of atopy, the distribution of wheeze by age, sex, smoking status, and by social class was examined.
All analyses were carried out using SPSS 10.0 for Windows (SPSS Inc, Chicago, USA).

\section{RESULTS}

A total of 18434 households participated in the survey (78\% of eligible households). There is no information on the characteristics of households who did not participate except that they were more frequently located in urban areas. Within participating households, 32498 adults (93\%) and 2504 children aged 11-15 (98\%) were interviewed. Among the people who were not interviewed there was a higher proportion of males and younger age groups. Of the 35002 people interviewed, $24952(71 \%)$ provided blood samples sufficient for assays of both total IgE and HDM IgE. The characteristics of those giving a blood sample were broadly similar to the overall sample group except in respect of age. Only 56\% (2385/4246) of the 11-19 age group had a usable blood sample.

\section{Wheezing diagnosed as asthma $v$ wheezing without an asthma diagnosis}

Overall, 5173 subjects $(20.7 \%)$ reported wheezing in the past year, of whom 2047 (39.6\%) had been given a diagnosis of asthma by a doctor at any time. The percentage of subjects with wheeze in the past year but no diagnosis of asthma increased with increasing total IgE (table 1). However, the increase in total IgE of subjects with wheeze in the past year and a diagnosis of asthma was much greater. Individuals with raised HDM IgE were more likely to have wheeze with an asthma diagnosis than wheeze not labelled as asthma.

Odds ratios for wheeze with and without a diagnosis of asthma compared with the no wheeze group are shown in table 2. Wheeze in the past year without an asthma diagnosis was more common in men and older age groups, whereas wheeze with an asthma diagnosis was more common in women and there was no consistent age gradient after adjustment for IgE. Both types of wheeze were more common in the lower social classes, ex-smokers and current smokers, and those living in urban areas. However, the effects of social class and of smoking were more marked in the group without an asthma diagnosis. 
Table 2 Odds ratios for the risk factors for the presence of wheeze in the past year with and without an asthma diagnosis with adjustment for lgE levels

\begin{tabular}{|c|c|c|c|c|c|c|c|}
\hline & \multirow[b]{2}{*}{ No } & \multicolumn{3}{|c|}{$\begin{array}{l}\text { Wheeze in the past year without a diagnosis of } \\
\text { asthma }\end{array}$} & \multicolumn{3}{|c|}{ Wheeze in the past year and diagnosis of asthma } \\
\hline & & Adjusted* OR & $95 \% \mathrm{Cl}$ & $\mathrm{p}$ value** & Adjusted* OR & $95 \% \mathrm{Cl}$ & $\mathrm{p}$ value ${ }^{* *}$ \\
\hline \multicolumn{8}{|l|}{ Sex } \\
\hline Female & 13021 & 1 & (reference) & 0.001 & 1 & (reference) & $<0.001$ \\
\hline Male & 11929 & 1.16 & 1.07 to 1.25 & & 0.63 & 0.57 to 0.69 & \\
\hline \multicolumn{8}{|c|}{ Age } \\
\hline $11-19$ & 2385 & 1 & (reference) & $<0.001$ & 1 & (reference) & 0.561 \\
\hline $20-29$ & 3371 & 1.10 & 0.90 to 1.35 & & 0.91 & 0.75 to 1.09 & \\
\hline $30-39$ & 4726 & 1.01 & 0.84 to 1.23 & & 0.66 & 0.55 to 0.79 & \\
\hline $40-49$ & 4399 & 1.31 & 1.08 to 1.58 & & 0.65 & 0.53 to 0.78 & \\
\hline $50-59$ & 3529 & 1.53 & 1.26 to 1.86 & & 0.74 & 0.61 to 0.91 & \\
\hline $60-69$ & 3209 & 1.87 & 1.54 to 2.27 & & 0.88 & 0.72 to 1.08 & \\
\hline $70-79$ & 2366 & 2.16 & 1.76 to 2.65 & & 0.96 & 0.77 to 1.19 & \\
\hline $80-89$ & 885 & 2.25 & 1.74 to 2.90 & & 0.83 & 0.60 to 1.14 & \\
\hline $90+$ & 80 & 2.87 & 1.55 to 5.30 & & 0.15 & 0.02 to 1.08 & \\
\hline \multicolumn{8}{|c|}{ Social class*** } \\
\hline I & 1646 & 1 & (reference) & $<0.001$ & 1 & (reference) & $<0.001$ \\
\hline ॥ & 7302 & 1.16 & 0.96 to 1.42 & & 0.94 & 0.77 to 1.16 & \\
\hline IIInm & 3246 & 1.22 & 0.99 to 1.51 & & 0.93 & 0.74 to 1.17 & \\
\hline $\mathrm{Illm}$ & 7095 & 1.54 & 1.27 to 1.87 & & 1.12 & 0.91 to 1.37 & \\
\hline IV & 3299 & 1.42 & 1.16 to 1.75 & & 1.12 & 0.89 to 1.40 & \\
\hline V & 1204 & 1.56 & 1.23 to 1.99 & & 1.27 & 0.96 to 1.68 & \\
\hline \multicolumn{8}{|l|}{ Urban/rural } \\
\hline Rural & 5945 & 1 & (reference) & 0.002 & 1 & (reference) & 0.106 \\
\hline Urban & 19005 & 1.17 & 1.06 to 1.29 & & 1.10 & 0.98 to 1.24 & \\
\hline \multicolumn{8}{|l|}{ Smoking } \\
\hline Never & 6822 & 1 & (reference) & & 1 & (reference) & \\
\hline Ex & 9894 & 1.61 & 1.45 to 1.79 & $<0.001$ & 1.50 & 1.33 to 1.71 & $<0.001$ \\
\hline Current & 6240 & 3.41 & 3.09 to 3.76 & $<0.001$ & 1.43 & 1.27 to 1.62 & $<0.001$ \\
\hline \multicolumn{8}{|l|}{ Total lgE } \\
\hline $0-3$ & 2400 & 1 & (reference) & $<0.001$ & 1 & (reference) & $<0.001$ \\
\hline $4-9$ & 2907 & 1.05 & 0.88 to 1.27 & & 1.03 & 0.77 to 1.37 & \\
\hline $10-31$ & 6109 & 1.09 & 0.93 to 1.27 & & 1.23 & 0.96 to 1.58 & \\
\hline $32-99$ & 6501 & 1.12 & 0.96 to 1.31 & & 1.80 & 1.42 to 2.29 & \\
\hline $100-315$ & 4624 & 1.34 & 1.14 to 1.59 & & 2.58 & 2.02 to 3.29 & \\
\hline $316-999$ & 1850 & 1.50 & 1.23 to 1.84 & & 3.30 & 2.54 to 4.31 & \\
\hline $1000+$ & 559 & 1.28 & 0.94 to 1.75 & & 3.93 & 2.85 to 5.41 & \\
\hline \multicolumn{8}{|l|}{$\mathrm{HDM} \lg \mathrm{E}$} \\
\hline $0-0.3$ & 20004 & 1 & (reference) & $<0.001$ & 1 & (reference) & $<0.001$ \\
\hline $0.4-10.0$ & 3134 & 1.10 & 0.97 to 1.25 & & 1.77 & 1.54 to 2.04 & \\
\hline$>10$ & 1812 & 1.51 & 1.26 to 1.81 & & 4.50 & 3.84 to 5.26 & \\
\hline
\end{tabular}

*Adjustment is for all variables listed.

** Significance levels are based on a test for heterogeneity except for age and social class which are based on tests for trend using ordered categories. *** I=professional; II=managerial; IIInm=clerical; IIIm=skilled manual; IV=semi-skilled manual; V=unskilled manual.

The odds ratios displayed in table 2 were adjusted for both total and HDM IgE. The effect of this adjustment on the odds ratios for other variables was very limited. For wheeze without an asthma diagnosis, adjusting for IgE had little effect on the size or significance of the odds ratios for the other factors. For wheeze with a doctor diagnosis, adjustment for IgE eliminated the age trend so that it was more common in younger age groups. Both total and HDM IgE were much more strongly related to wheeze with a doctor diagnosis than to wheeze without a diagnosis. This suggests that IgE mediated allergy is a more important risk factor than the demographic and lifestyle factors studied for wheeze with an asthma diagnosis.

The data in table 2 were re-analysed in table 3 using only those individuals who reported never having smoked. Male sex and urban location were no longer significantly associated with wheeze without an asthma diagnosis and social class was no longer associated with wheeze with a diagnosis. These differences may represent underadjustment for smoking in table 2. Wheeze without an asthma diagnosis continued to be associated with older age and lower social class, whereas wheeze diagnosed as asthma was related to female sex and younger age and was more strongly related to total IgE and HDM IgE levels than wheeze without a diagnosis.

Overall there was a clear indication that the risk factors for wheeze with and without an asthma diagnosis were different.

\section{Atopic $v$ non-atopic wheeze}

When the population was divided into three categories of atopy, $10736(43.0 \%)$ were classified as non-atopic, 9268 $(37.2 \%)$ as intermediate, and $4943(19.8 \%)$ as atopic. Of the non-atopic group, $15.4 \%$ had experienced wheeze in the past year and, of these, $26.9 \%$ also had a diagnosis of asthma. In the atopic group $31.3 \%$ had experienced wheeze in the past year, of which $58.2 \%$ had a diagnosis of asthma. It is clear that both wheezing in the past year and having a diagnosis of asthma were associated with atopy. However, nearly a third $(32.0 \%)$ of those reporting wheezing did not have raised total or HDM IgE and, of those with an asthma diagnosis, $21.7 \%$ did not have raised IgE.

Among non-atopic individuals the prevalence of wheeze increased with age (fig l). This trend was due to the contribution of wheeze without a diagnosis of asthma and, in contrast, 
Table 3 Odds ratios for the risk factors for the presence of wheeze in the past year with and without an asthma diagnosis with adjustment for IgE levels for individuals who had never smoked

\begin{tabular}{|c|c|c|c|c|c|c|c|}
\hline & \multirow[b]{2}{*}{$\mathrm{N}$} & \multicolumn{3}{|c|}{$\begin{array}{l}\text { Wheeze in the past year without a diagnosis of } \\
\text { asthma }\end{array}$} & \multicolumn{3}{|c|}{ Wheeze in the past year and diagnosis of asthma } \\
\hline & & Adjusted* OR & $95 \% \mathrm{Cl}$ & $\mathrm{p}$ value** & Adjusted* OR & $95 \% \mathrm{Cl}$ & $\mathrm{p}$ value ${ }^{* *}$ \\
\hline \multicolumn{8}{|l|}{ Sex } \\
\hline Female & 7010 & 1 & (reference) & 0.971 & 1 & (reference) & $<0.001$ \\
\hline Male & 5082 & 1.00 & 0.86 to 1.16 & & 0.71 & 0.61 to 0.83 & \\
\hline \multicolumn{8}{|l|}{ Age } \\
\hline $11-19$ & 1838 & 1 & (reference) & $<0.001$ & 1 & (reference) & 0.009 \\
\hline $20-29$ & 1703 & 0.88 & 0.64 to 1.21 & & 0.95 & 0.75 to 1.20 & \\
\hline $30-39$ & 2451 & 1.19 & 0.91 to 1.57 & & 0.62 & 0.49 to 0.79 & \\
\hline $40-49$ & 1931 & 1.54 & 1.17 to 2.04 & & 0.75 & 0.58 to 0.97 & \\
\hline $50-59$ & 1432 & 1.81 & 1.35 to 2.42 & & 0.61 & 0.44 to 0.83 & \\
\hline $60-69$ & 1356 & 1.80 & 1.34 to 2.42 & & 0.77 & 0.57 to 1.04 & \\
\hline 70-79 & 904 & 2.10 & 1.52 to 2.89 & & 0.89 & 0.63 to 1.25 & \\
\hline $80-89$ & 430 & 2.93 & 2.03 to 4.25 & & 0.66 & 0.39 to 1.12 & \\
\hline $90+$ & 47 & 2.51 & 0.95 to 6.60 & & 0.02 & 0.00 to 32.52 & \\
\hline \multicolumn{8}{|c|}{ Social class*** } \\
\hline I & 1031 & 1 & (reference) & 0.009 & 1 & (reference) & 0.618 \\
\hline$\|$ & 3900 & 1.15 & 0.86 to 1.54 & & 0.80 & 0.61 to 1.04 & \\
\hline IIInm & 1632 & 1.15 & 0.83 to 1.60 & & 0.84 & 0.61 to 1.14 & \\
\hline IIIm & 3054 & 1.44 & 1.07 to 1.94 & & 0.89 & 0.68 to 1.17 & \\
\hline IV & 1382 & 1.31 & 0.94 to 1.84 & & 0.90 & 0.65 to 1.23 & \\
\hline V & 489 & 1.41 & 0.93 to 2.14 & & 0.80 & 0.51 to 1.24 & \\
\hline \multicolumn{8}{|l|}{ Urban/rural } \\
\hline Rural & 2992 & 1 & (reference) & 0.099 & 1 & (reference) & 0.933 \\
\hline Urban & 9100 & 1.16 & 0.97 to 1.37 & & 0.99 & 0.83 to 1.18 & \\
\hline \multicolumn{8}{|l|}{ Log total lgE } \\
\hline $0-3$ & 1312 & 1 & (reference) & 0.013 & 1 & (reference) & $<0.001$ \\
\hline $4-9$ & 1547 & 1.01 & 0.74 to 1.39 & & 1.46 & 0.88 to 2.40 & \\
\hline $10-31$ & 2970 & 1.08 & 0.87 to 1.44 & & 1.64 & 1.04 to 2.58 & \\
\hline $32-99$ & 3024 & 1.07 & 0.81 to 1.42 & & 2.72 & 1.76 to 4.21 & \\
\hline $100-315$ & 2132 & 1.35 & 1.00 to 1.82 & & 3.69 & 2.37 to 5.74 & \\
\hline $316-999$ & 847 & 1.55 & 1.08 to 2.24 & & 4.49 & 2.80 to 7.18 & \\
\hline $1000+$ & 260 & 1.08 & 0.58 to 1.99 & & 7.01 & 4.15 to 11.85 & \\
\hline \multicolumn{8}{|l|}{ HDM lgE } \\
\hline $0-0.3$ & 9587 & 1 & (reference) & $<0.001$ & 1 & (reference) & $<0.001$ \\
\hline $0.4-10.0$ & 1436 & 1.26 & 1.00 to 1.59 & & 2.01 & 1.62 to 2.48 & \\
\hline$>10$ & 1069 & 2.07 & 1.56 to 2.74 & & 4.92 & 3.96 to 6.11 & \\
\hline
\end{tabular}

there was no relationship between age and wheeze and an asthma diagnosis. In atopic individuals there was a small increase in the prevalence of wheeze without an asthma diagnosis with increasing age, whereas for wheeze diagnosed as asthma there was an inverse relationship with age. All these relationships between age and wheeze prevalence persisted after adjustment for sex, social class, smoking, and urban/ rural location.

Wheezing was more common in smokers than in nonsmokers, whatever the atopic status (data not shown). However, among atopic individuals the relationship was less marked and there was no relationship between smoking and wheeze with a diagnosis of asthma in atopic individuals (data not shown).

In non-atopic individuals the prevalence of wheeze was related to social class with a higher prevalence in social classes IV and V (fig 2). However, in atopic subjects there was no significant social class trend following adjustment for age.

The significant risk factors for wheeze in the past year compared with no wheeze in non-atopic subjects were older age, lower social class, urban location, and smoking (table 4). In atopic subjects, female sex and smoking were the only significant risk factors and the effect of current smoking was smaller than for non-atopic subjects. When comparing atopic with non-atopic subjects, there was a significant difference in all the risk factors for wheeze except urban versus rural location and former smoking.

\section{DISCUSSION}

\section{Study population}

This study has used the largest published data set of serum $\mathrm{IgE}$ measurements. The sample is representative of the population of England living in private households and covers a wide age range. It is a general health survey and, as such, avoids problems of response bias seen in surveys specifically about respiratory symptoms or allergy where atopic people may be more likely to cooperate. ${ }^{13}$

\section{Response rate}

There was an overall under-representation of younger age groups which is likely to have caused an underestimation of the proportion of the population with atopy and the proportion of those who wheeze who have doctor diagnosed asthma. However, it seems improbable that the overall relationships between demographic factors and either wheezing or atopy would be significantly altered by this.

\section{Classification of smoking status}

The use of three categories of smoking (never, ex, and current smoking) may oversimplify the degree of exposure to cigarette 


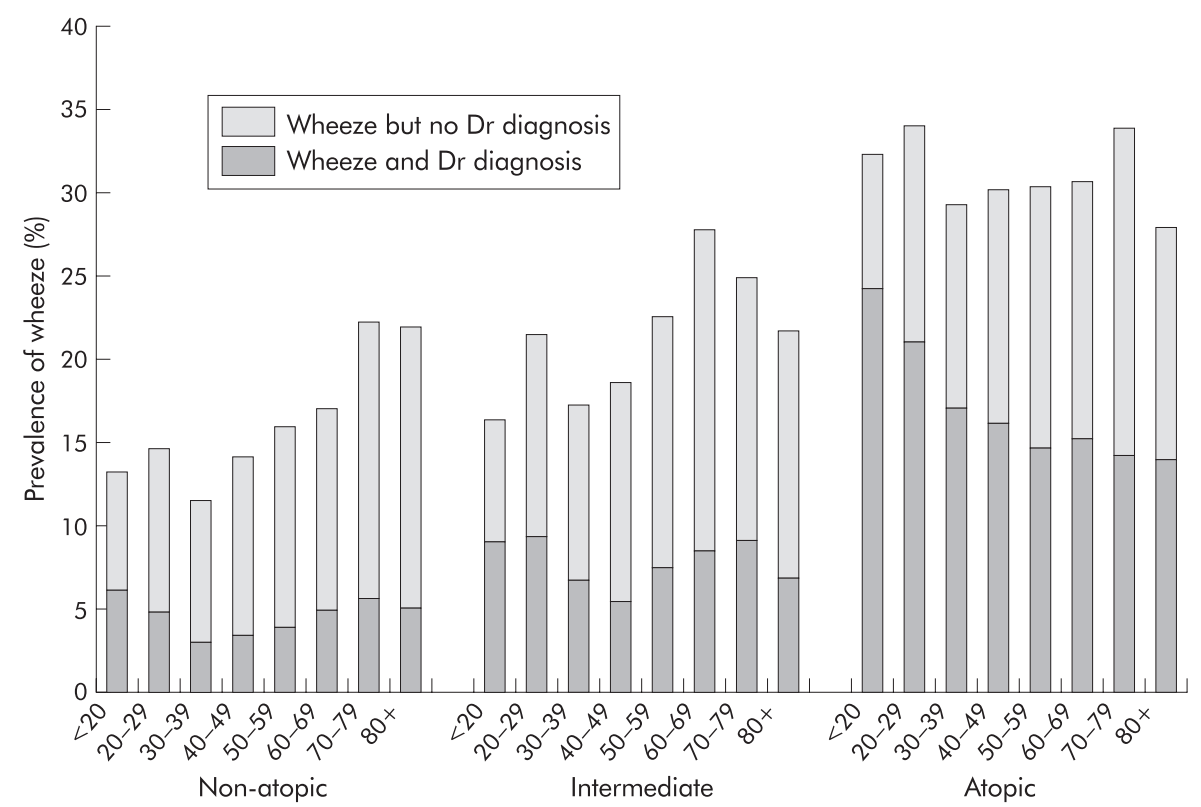

Figure 1 Prevalence of wheeze by atopic status and age.

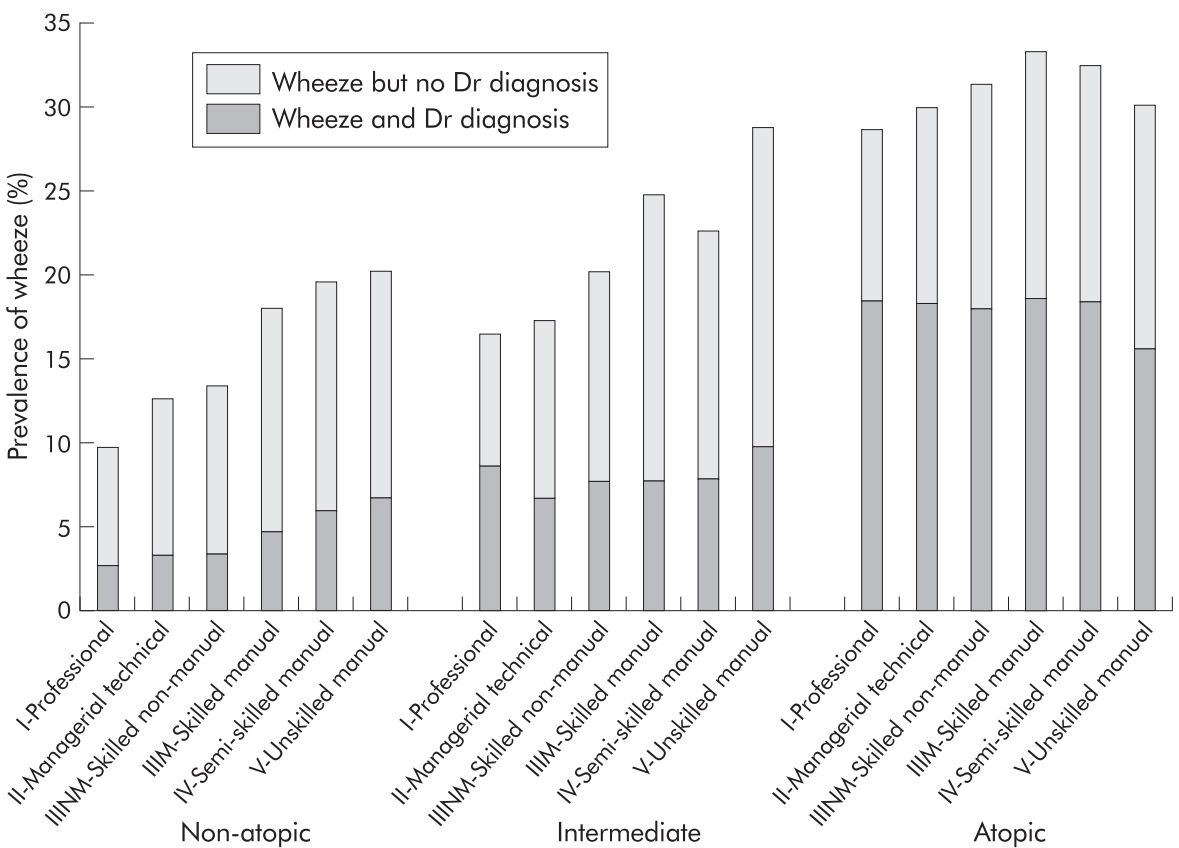

Figure 2 Prevalence of wheeze by atopic status and social class.

smoke and result in underadjustment for smoking. The categories were chosen because of difficulty in classifying smoking consistently across all age groups as younger age groups were asked different questions from adults about smoking habits. An advantage of this study, however, is that there are sufficient subjects who have never smoked (12 092) to look at this group separately (table 3).

\section{Identifying atopic status}

Previous studies have used a variety of methods to identify subjects with atopy including measuring specific IgE to a range of common allergens, ${ }^{12}{ }^{14-16}$ skin prick testing, ${ }^{15}$ and selfreported hay fever. ${ }^{16}$ Total IgE level alone has been used as an indication of atopy where levels of $<20 \mathrm{kU} / \mathrm{l}$ indicate that atopy is improbable and $>100 \mathrm{kU} / \mathrm{l}$ that atopy is probable. ${ }^{16} \mathrm{In}$ this study skin prick testing was not carried out and only total and HDM IgE were measured, so our definition of atopy has been limited to these two measurements. The intermediate category was used for subjects whose atopic status could not be determined from these two measures. A study of Dutch subjects showed that HDM IgE was raised more often than that of the other common aeroallergens and $67 \%$ of all subjects with one or more raised specific IgE had raised HDM IgE. ${ }^{13}$ Assuming that a similar pattern holds in our population, one third of all atopic individuals would be missed from our atopic category. Previous studies have shown that total IgE is related to atopic status ${ }^{13}{ }^{16}$ with large differences in geometric mean total IgE between those with no raised specific IgE and those with at least one raised specific IgE. However, there is an overlap in ranges, so it is possible that some atopic subjects have total $\operatorname{IgE}<30 \mathrm{kU} / \mathrm{l}$ and appear in the non-atopic group.

\section{Wheeze $\boldsymbol{v}$ asthma diagnosis}

Our finding that only $40 \%$ of those with wheeze had received a diagnosis of asthma is in line with previous studies. ${ }^{17}$ Women and younger subjects are more likely and current 
Table 4 Odds ratios for the risk factors for the presence of wheeze in the past year for non-atopic and atopic individuals

\begin{tabular}{|c|c|c|c|c|c|c|c|}
\hline & \multicolumn{3}{|c|}{ Wheeze in the past year in non-atopics } & \multicolumn{3}{|c|}{ Wheeze in the past year in atopics } & \multirow{2}{*}{$\begin{array}{l}\text { p value** } \\
\text { (difference } \\
\text { between atopics } \\
\text { and non-atopics) }\end{array}$} \\
\hline & Adjusted* OR & $95 \% \mathrm{Cl}$ & p value ${ }^{* *}$ & Adjusted* OR & $95 \% \mathrm{Cl}$ & p value ${ }^{* *}$ & \\
\hline \multicolumn{8}{|l|}{ Sex } \\
\hline Female & 1 & (reference) & 0.460 & 1 & (reference) & $<0.001$ & $<0.001$ \\
\hline Male & 1.04 & 0.93 to 1.17 & & 0.76 & 0.67 to 0.86 & & \\
\hline \multicolumn{8}{|l|}{ Age } \\
\hline $11-19$ & 1 & (reference) & $<0.001$ & 1 & (reference) & 0.129 & $<0.001$ \\
\hline $20-29$ & 0.79 & 0.60 to 1.04 & & 0.90 & 0.73 to 1.12 & & \\
\hline $30-39$ & 0.66 & 0.50 to 0.85 & & 0.73 & 0.59 to 0.91 & & \\
\hline $40-49$ & 0.85 & 0.66 to 1.10 & & 0.79 & 0.62 to 0.99 & & \\
\hline $50-59$ & 1.01 & 0.78 to 1.31 & & 0.78 & 0.60 to 1.02 & & \\
\hline $60-69$ & 1.17 & 0.90 to 1.52 & & 0.80 & 0.60 to 1.06 & & \\
\hline 70-79 & 1.70 & 1.31 to 2.22 & & 0.93 & 0.66 to 1.32 & & \\
\hline 80-89 & 1.81 & 1.31 to 2.50 & & 0.78 & 0.39 to 1.57 & & \\
\hline $90+$ & 2.49 & 1.07 to 5.81 & & 0.36 & 0.04 to 3.16 & & \\
\hline \multicolumn{8}{|c|}{ Social class*** } \\
\hline 1 & 1 & (reference) & $<0.001$ & 1 & (reference) & 0.759 & $<0.001$ \\
\hline ॥ & 1.22 & 0.93 to 1.60 & & 1.03 & 0.80 to 1.32 & & \\
\hline IIInm & 1.20 & 0.89 to 1.61 & & 1.02 & 0.76 to 1.35 & & \\
\hline IIIm & 1.60 & 1.22 to 2.09 & & 0.13 & 0.87 to 1.45 & & \\
\hline IV & 1.68 & 1.26 to 2.23 & & 1.03 & 0.77 to 1.37 & & \\
\hline v & 1.67 & 1.18 to 2.34 & & 0.93 & 0.63 to 1.36 & & \\
\hline \multicolumn{8}{|c|}{ Urban/rural } \\
\hline Rural & 1 & (reference) & 0.010 & 1 & (reference) & 0.131 & 0.596 \\
\hline Urban & 1.19 & 1.04 to 1.36 & & 1.13 & 0.97 to 1.31 & & \\
\hline \multicolumn{8}{|l|}{ Smoking } \\
\hline Never & 1 & (reference) & & 1 & (reference) & & \\
\hline Ex & 1.56 & 1.35 to 1.80 & $<0.001$ & 1.29 & 1.09 to 1.53 & 0.004 & 0.095 \\
\hline Current & 3.36 & 2.93 to 3.85 & $<0.001$ & 1.64 & 1.41 to 1.90 & $<0.001$ & $<0.001$ \\
\hline
\end{tabular}

*Adjustment for all variables listed.

** Significance levels are based on a test for heterogeneity except for age and social class which are based on tests for trend using ordered categories. ***I=professional; II=managerial; IIInm=clerical; IIIm=skilled manual; IV=semi-skilled manual; V=unskilled manual.

smokers less likely to receive a diagnosis of asthma. These differences could be a reflection of the determinants of labelling-for example, doctors' reluctance to label wheezing as asthma in older people or smokers ${ }^{18}$ - or they may reflect separate diseases. Wheezing not diagnosed as asthma may represent a distinct form of asthma such as non-atopic asthma or it may be a different condition. Chronic obstructive pulmonary disease is an obvious candidate, particularly in older people and smokers, but there are subjects with wheeze and no asthma diagnosis across the whole age range and among never smokers. Alternatively, the differences may reflect use of health services-for example, men are less likely to seek a doctor's opinion-or the ability to recall being given a diagnosis. ${ }^{19}$ Whatever the reasons, this study shows that those diagnosed as asthmatic are more likely than other individuals with wheeze to be atopic. However, of those with wheeze and raised HDM IgE levels, $41.8 \%$ are not diagnosed as asthmatic.

Some epidemiological studies used symptom based questions to identify asthma while others use doctor diagnosed asthma. It is clear from this study that these two approaches will identify different populations and this should be given consideration in study design. Using a diagnosis of asthma misses a large group of atopic adults who wheeze.

\section{IgE $v$ non-IgE mediated asthma}

The results suggest that at least one third of people who wheeze and one fifth of those diagnosed as asthmatic are not atopic. Among non-atopic subjects, wheeze is more prevalent in older age groups, lower social classes, smokers, and in urban locations. This is consistent with the concept of non-atopic or intrinsic asthma and contrasts with the conclusions of Burrows et al $^{1}$ that asthma is almost always associated with some type of IgE related reaction. Pearce et $a l^{20}$ showed that the proportion of asthma cases attributable to atopy is usually less than one half even if the two studies of adult onset wheezing are excluded. Following an approach similar to that of Pearce et al, we estimated the proportion of wheezing in the last year which was statistically attributable to IgE mediated allergy using an inclusive definition of atopy (intermediate and atopic groups combined, accounting for over half of the population in each age group). Among subjects of all ages, the proportion of recent wheezing attributable to atopy (population attributable risk fraction or aetiological fraction) was $26 \%$; this aetiological fraction was $35 \%$ in those aged $11-29$ years, $30 \%$ in those aged $30-49,25 \%$ in the $50-69$ age group, and only $7 \%$ among those aged over 70 years.

Pearce $e t \mathrm{al}^{20}$ concluded that the importance of atopy as a cause of asthma may have been overemphasised and other aetiological mechanisms neglected. Our findings support this view. It may therefore be advisable to consider IgE mediated and non-IgE mediated asthma separately when investigating factors in the aetiology of asthma such as indoor and outdoor air pollution, genetics, and diet.

\section{ACKNOWLEDGEMENTS}

The authors thank all those who agreed to participate in the survey, the interviewers and nurses, the staff at the Department of Clinical Biochemistry at the West Middlesex University Hospital, the UK Data Archive, and the depositors of the information for permission to use the data. Material from the Health Survey for England is Crown Copyright and has been made available by the Office of National Statistics, the Joint Health Surveys Unit of Social and Community Planning Research, and the Department of Epidemiology and Public Health at University College, London. Neither the depositors nor the 
Data Archive bear any responsibility for the analysis or interpretation of the data reported here.

\section{Authors' affiliations}

C S Court, D G Cook, D P Strachan, Department of Public Health Sciences, St George's Hospital Medical School, London SW17 ORE, UK

\section{REFERENCES}

1 Burrows B, Martinez FD, Halonen M, et al. Association of asthma with serum lgE levels and skin-test reactivity to allergens. N Engl J Med 1989:320:271-7.

2 Tollerud DJ, O'Connor GT, Sparrow D, et al. Asthma, hay fever, and phlegm production associated with distinct patterns of allergy skin test reactivity, eosinophilia, and serum IgE levels. The Normative Aging Study. Am Rev Respir Dis 1991;144:776-81.

3 Barbee RA, Halonen M, Kaltenborn WT, et al. A longitudinal study of respiratory symptoms in a community population sample. Correlations with smoking, allergen skin-test reactivity, and serum. Chest 1991;99:20-6.

4 Sperber K, Kendler D, Yu LM, et al. Prevalence of atopy in an inner-city asthmatic population. Mount Sinai J Med 1993;60:227-31.

5 Selassie FG, Stevens RH, Cullinan P, et al. Total and specific lgE (house dust mite and intestinal helminths) in asthmatics and controls from Gondar, Ethiopia. Clin Exp Allergy 2000;30:356-8.

6 Tang RB, Tsai LC, Hwang HM, et al. The prevalence of allergic disease and $\operatorname{lgE}$ antibodies to house dust mite in schoolchildren in Taiwan. Clin Exp Allergy 1990;20:33-8.

7 Turner KJ, Baldo BA, Anderson HR. Asthma in the highlands of New Guinea: total $\lg E$ levels and incidence of $\lg E$ antibodies to house dust mite and Ascaris lumbricoides. Int Arch Allergy Appl Immunol 1975;48:784-99.

8 Sears MR, Burrows B, Flannery EM, et al. Relation between airway responsiveness and serum $\lg E$ in children with asthma and in apparently normal children. N Engl J Med 1991;325:1067-71.
9 Sunyer J, Anto J, Castellsague, et al. Total serum lgE is associated with asthma independently of specific lgE levels. Eur Respir J

1996:9:1880-4.

10 Prescott-Clarke P, Primatesta P, eds. Health survey for England 1995. London: The Stationery Office, 1997.

11 Prescott-Clarke P, Primatesta P, eds. Health survey for England 1996. London: The Stationery Office, 1998.

12 Burney P, Malmberg E, Chinn S, et al. The distribution of total and specific serum lgE in the European Community Respiratory Health Survey. J Allergy Clin Immunol 1997;99:314-22.

13 Kerkhof $M$, Droste JH, de Monchy JG, et al. Distribution of total serum $\lg E$ and specific $\lg E$ to common aeroallergens by sex and age, and their relationship to each other in a random sample of the Dutch general population aged 20-70 years. Dutch ECRHS Group, European Community Respiratory Health Study. Allergy 1996;51:770-6.

14 Jarvis D, Luczynska C, Chinn S, et al. The association of age, gender and smoking with total $\lg \mathrm{E}$ and specific $\lg \mathrm{E}$. Clin Exp Allergy 1995;25:1083-91.

15 Kalyoncu AF, Stalenheim G. Serum lgE levels and allergic spectra in immigrants to Sweden. Allergy 1992;47:277-80.

16 Wuthrich B, Schindler C. Medici TC, et al. IgE levels, atopy markers and hay fever in relation to age, sex and smoking status in a normal adult Swiss population. SAPALDIA (Swiss Study on Air Pollution and Lung Diseases in Adults) Team. Int Arch Allergy Immunol 1996;1 11:396-402.

17 Dodge RR, Burrows B. The prevalence and incidence of asthma and asthma-like symptoms in a general population sample. Am Rev Respir Dis 1980;122:567-75.

18 Littlejohns P, Ebrahim S, Anderson HR. Prevalence and diagnosis of chronic respiratory symptoms in adults. BM 1989;298:1556-60.

19 McWhorter WP, Polis MA, Kaslow RA. Occurrence, predictors, and consequences of adult asthma in NHANESI and follow-up survey. Am Rev Respir Dis 1989;139:721-4.

20 Pearce N, Pekkanen J, Beasley R. How much asthma is really attributable to atopy? Thorax 1999;54:268-72. 